\title{
Whose Governance? IMF Austerities in a Small Island State: The Case of Jamaica
}

\author{
Ann Marie Bissessar
}

\author{
Department of Public Management and Behavioural Sciences, The University of the West Indies, St. \\ Augustine Campus, Trinidad, West Indies
}

\begin{abstract}
The International Monetary Fund and the World Bank have for a long time embarked on what can be described as a 'trustee' relationship with countries in the Commonwealth Caribbean. From the latter half of the 1970s, countries such as Trinidad and Tobago, Guyana, Barbados as well as Grenada were 'forced' because of their chronic need for 'hard' currency loans to approach the IMF and the World Bank. These loans were accompanied by structural adjustment measures. This paper attempts, for the first time, to evaluate, in the case of Jamaica, whether the measures introduced by the Lending Agencies resulted in some measure of economic growth in the countries under review. The paper then examines the new agreements entered into by these countries and the measures that accompanied them. The overarching argument is that the forces of globalization as well as austerity measures introduced by lending agencies such the IMF and the World Bank prevents rather than encourages small island governments ${ }^{1}$ to embark on 'national' development plans and programs. In other words, the primary argument of this paper is that these countries are constrained in their ability to 'govern' themselves; rather their economic decisions are largely crafted by the forces of globalization and further reinforced by international lending agencies such as the World Bank and the International Monetary Fund.
\end{abstract}

Keywords: International Monetary Fund (IMF), World Bank (WB), Jamaica, Globalization, National Development, Structural Adjustment, Agreements.

\section{INTRODUCTION}

The concept of the 'dependency' of small island developing states on larger metropolitan countries is by no means new. Rathersince the 1950 s, writers such as Furtado $(1963)^{2}$, Girvan $(2002)^{3}$ Beckford $(2000)^{4}$ and Best and Levitt $(2007)^{5}$, concluded that the Caribbean countries, more particularly small states, have to a large extent been unable to wean themselves from

*Address correspondence to this author at the Department of Public Management and Behavioural Sciences, The University of the West Indies, St. Augustine Campus, Trinidad, West Indies; Tel: 1-868-669-0286;

Fax: 1- 868-663-4948; E-mail: Annmarie.bissessar@sta.uwi.edu

\footnotetext{
'A common feature of 'small' states is that these are countries with populations of less than 1.5 million people. According to the World Bank, there are forty eight such countries, eleven located in Africa, twelve in the Caribbean, fifteen in Asia-Pacific, and ten in other regions of the world. Some of these countries are island states while others are landlocked. Essentially, though, it is suggested that these countries suffer from three major impediments, namely:

-Diseconomies of scale in production, marketing, distribution, and public administration;

-Exposure to high levels of risk because of small populations and limited physical space; and

-Limited scope and capacity for negotiating with larger states and private sector entities.

${ }^{2}$ Furtado, C. (1963) the Economic Growth of Brazil, Berkeley: University of California Press.

${ }^{3}$ Girvan, N. (2002) "Notes for a Retrospective on the Theory of Plantation Economy of Lloyd Best and Kari Polanyi Levitt," in M-C Dernò and K.Nurse (eds.) Caribbean Economies and Global Restructuring, Kingston, Jamaica: lan Randle Publishers for the Association of Caribbean Economists.

${ }^{4}$ Beckford, G.L. (2000) "The Future of Plantation Society in Comparative Perspective," in G.L. Beckford and K. Polanyi Levitt, The George Beckford Papers: Selected and Introduced by Kari Levitt, Mona, Jamaica: Canoe Press, University of the West Indies, 336-46.

${ }^{5}$ Best, L. and K. Polanyi Levitt (2007) Plantation Economy: A Historical and Institutional Approach To Caribbean Economic Transformation, Mona, Jamaica: University of the West Indies Press.
}

their colonial past. Indeed, even today many of these countries still maintain mono economies and depend on countries such as the United States, the United Kingdom and more recently China for much of their basic needs including food, clothing, and technology and to some extent even 'ideas.' The dependency writers suggest that these countries were 'conditioned' to be both economically as well as psychologically dependent on the larger countries even as they attained independence. This article will carry the discussion of dependency even further. It is suggested that to date many of these Caribbean small island states, due to sometimes poor domestic policies or global forces, remain largely indebted to the International Lending Agencies such as the World Bank (WB) and the International Monetary Fund (IMF). The end result is that many of their policies, programmes, and development plans are influenced by these agencies and may be incongruous with the actual needs of the countries. The focus of this article will be on Jamaica, one country which has been currently classified as a Highly Indebted country.

\section{JAMAICA AND THE IMF EXPERIENCE}

The island of Jamaica is the fifth largest island country in the Caribbean. It is situated in the Caribbean Sea and is 10,990 square kilometres $(4,240$ sq. mi) in area. Geographically it lies about 145 kilometres (90 mi) south of Cuba, and 191 kilometres $(119 \mathrm{mi})$ west of Hispaniola. The 2000 census conducted in Jamaica 
JAMAICA GOVERNMENT DEBT TO GDP

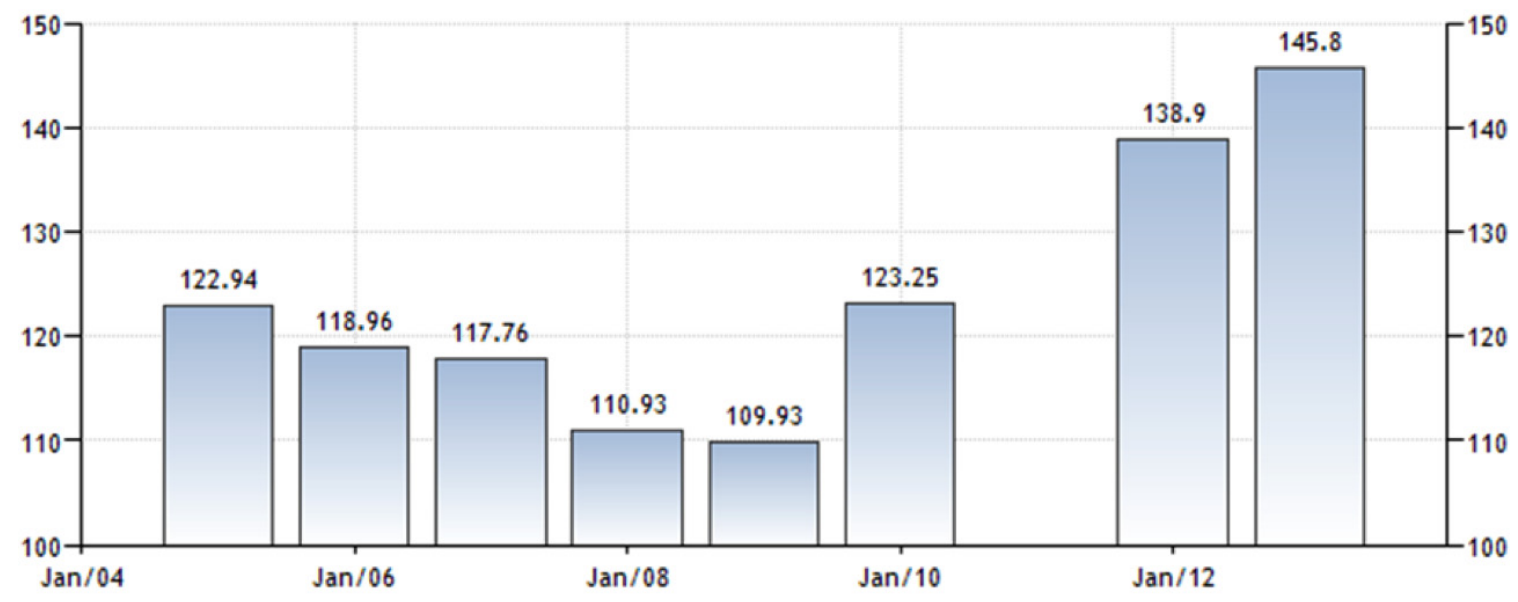

SOURCE: WWW.TRADINGECONOMCS.COM | BANK OF JAMAICA

Figure 1:

cites a population size of $2,652,689$ persons. While it has been famous for its reggae and sometimes its pristine tourist beaches, on the negative side, though, Jamaica has been ranked as one of the top ten nations whose debts are so huge that they are bigger than the size of their respective economies. According to Johnston (2013) during the period 1993- 2007, real Gross Domestic Product (GDP), in the case of Jamaica, averaged a mere $1.1 \%$ per year, which means that $16.5 \%$ of the population of this country are currently living well below the poverty line. According to the 2011 Human Development Report, the country ranked 78 out of 187 countries on the human development index based on indicators such as life expectancy at birth and expected years of schooling. The GDP per capita of the country during the period 1993- 2007 grew at an average of $0.4 \%$ while the debt to GDP was $100 \%$ in each year since $2001 .{ }^{6}$ (See Figure 1 above).

From the 1940s until the country attained independent status in 1962, it moved from being primarily an agricultural based economy to one based on mineral production (specifically bauxite) ${ }^{7}$ and tourism. During the period 1950 and 1962, the nominal GDP grew on average by $5 \%$ per year. However, after independence in 1962, one of the major concerns was that there were little improvements in the standard of living of the population. One of the major challenges, of

\footnotetext{
${ }^{6}$ Jake Johnston. 2013. The Multilateral debt Trap in Jamaica. Centre for Economic Policy Research, June: 1

${ }^{7}$ In 1960 , Jamaica supplied $28 \%$ of the world's bauxite
}

course, was that during this period, the manufacturing, financial, and almost all the large companies remained under foreign control. The implications for the retention of the major industries by foreign companies were far reaching. Indeed, profits would not have been circulated inside the country but repatriated outside. In addition, the top echelons of the company would be manned by expatriate officers while wages for the local labour was significantly lower and would be held constant. Moreover, the emphasis of the colonial administrators at this time would not have been directed to infrastructural development or the developmental needs of the country as a whole. In the case of Jamaica, for example, during this period $40 \%$ of the sugar industry was under foreign control. The level of unemployment was also high, ranging from $13 \%$ to $24 \%{ }^{8}$ While this could have been ignored or perhaps minimized when the country was under British rule, by the 1960s on attaining independence, the expectations of the local population for improved standards of living placed increasing demands on the new government. Without revenue to establish much needed infrastructure, including roads, bridges, sewer, potable water supply, health and other services, the government of Jamaica was faced with the dilemma that confronts perhaps all newly independent countries. The challenge was that, without the metropolitan country to provide revenue, independent, but small,

\footnotetext{
${ }^{8}$ See Economic Integration in the Western Hemisphere edited by Contanza Valdez and Terry Roe, April, 1997, Proceedings of a Symposium Sponsored by the International Agricultural Trade Research Consortium and the InterAmerican Institute for Cooperation on Agriculture June 7-9, 1995 San Jose, Costa Rica
} 
Jamaica simply could not exist on its own. It was not surprising, then, that a Bank of Jamaica quarterly Monetary Policy Report (2009), noted that Jamaica became a member of the IMF on February 21, 1963, a few months after attaining independence. Four months later, Jamaica entered into a one-year Stand-By Arrangement (SBA) with the Fund, which permitted drawings up to a limit of SDR 10 million. The agreement, which expired in June 1964, was unutilised, according to a report by the Bank of Jamaica. Evidently, the newly independent territory was determined to chart its own destiny. Like all newly independent and 'sovereign' territories, given its continuing downward economic spiral, the 'think tanks' of the country conceived a policy which it referred to as its "Internal Design Plan." The very name suggested that it was to be a policy that was crafted to address the internal challenges confronting Jamaica. What the government failed to recognize were that Jamaica was also subject to more powerful global forces.

One major policy decision taken by the then government, as part of the Internal Design Plan, was to nationalise many of the industries. The state introduced corporations that took over large parts of the bauxite, tourism and agricultural sectors. Participation in the productive sectors was incorporated in the 1963- 1968 Five Year Plan. During the period 1972- 1980 (under the Manley Government), the government instituted the following prescriptions, namely:

*Wide-ranging price and trade controls,

*Increasing marginal taxes,

*Expanding government spending through a rapidly increasing public sector labour force,

*Raising transfers to newly created state-owned enterprises.

At this period, it should be noted, real interest rates were negative and incentive structures were geared toward local production. What was important, though, at least in the eyes of the government, was the promotion of the image of a strong government. To this end, some powerful state agencies were established such as the Prices Commission, the National Water Agency, the Port Authority and the Urban Development Corporation. Additionally, the government took control of three sugar factories when they were facing closure and set up the Sugar Industry Authority. In the tourism sector it established the Hotel Corporation of Jamaica Ltd. By the end of 1971, the government already owned or partially owned five hotels and was active in the development of resort areas. In 1969, the government also acquired the electricity company, the JPS, the domestic telephone company (JTC) in the early 1970 s and the Jamaica Omnibus Company in 1974. In other words, the Government of Jamaica had literally taken control of the commanding heights of the Jamaican economy. The question was- could this be sustained?

Data from Valdez and Roe (1997) suggest that at least one policy measure, namely, the taxation of the bauxite industry did contribute positively to increased government earnings from an average of US $\$ 30$ million during 1970 to 1973 to an average of US\$164 million during 1974 to 1977 . In addition, legislation with respect to minimum wage was introduced for certain categories of workers and maximum hours were instituted for some manufacturing enterprises. As it related to agriculture, a land distribution program was introduced which targeted small farmers. The government's position was that any parcel in excess of one hundred acres that was kept idle was to be repossessed by the government. There was also a diversification of trading away from Europe and North America to Latin America, CARICOM countries, Japan and the rest of the economy. The increase in the revenue of the government, offered the opportunity for the government to proceed with a number of its ambitious acquisition plans. With these plans in motion, by 1980 , then, the Government of Jamaica owned eight out of twelve sugar factories, producing $75 \%$ of the sugar input of the country and $50 \%$ of the room capacity in the hotel industry. It also began to actively take over manufacturing enterprises, and nationalized the then Barclays Bank to form the National Commercial Bank. ${ }^{9}$

By the end of 1980, the impact of these policies was far reaching. For instance, in the agricultural sector, during the period 1972-1980, the domestic crop sector increased by $16 \%$. On the other hand, though, the increasing control of the government in the export sector resulted in a sharp contraction in output. Perhaps, it was a case of trying to do too much too soon. Neither the best intentions of the government, nor the Cuban- Jamaican alliances, however, were sufficient to prevent the crisis that was to be the

\footnotetext{
${ }^{9}$ See Christopher Adam, William Cavendish and Percy S Mistry. Adjusting privatization. Case Studies from developing Countries. James Currey Ltd, Islington, London: 1992: 112.
} 
economic albatross of Jamaica from the period 1972present. The rapid expansion in the number of firms and state enterprises meant that by 1984 , the public enterprise sector alone accounted for $21 \%$ of the GDP. The major problem was that it was a sector that was performing badly. It was suggested that one of the challenges was due to political interference primarily as a result of a number of political appointments. Public accountability, on the other hand, was minimal. Clearly, the Internal Design Plans, while encompassing a number of areas, may have had some serious flaws. One of the primary flaws was, no doubt, the lack of proper mechanisms to regulate the enterprises.

In addition, however, to what can be described as a number of poorly conceived domestic policies, a number of global forces were also at play. One major challenge, for example, was that the Jamaican dollar was tied to the British pound. When the British pound weakened, speculation of devaluation within the Jamaican economy contributed to a decline in foreign investment from $\$ 147 \mathrm{mn}$ in 1971 to $\$ 21 \mathrm{mn}$ in 1972 . In order to prevent further haemorrhaging the government introduced a number of what can only be described as austerity measures. Included was the banning of import items that could be produced locally, a measure that was intended to reduce the outflow of foreign exchange; the pegging of the \$JM to the United States dollar $^{10}$; and measures to reduce the domestic consumption of oil.

As if these challenges were not enough, world inflation was felt strongly in Jamaica in 1973 when the price of staples such as corn, wheat, animal feeds and fertilizers soared. In addition, the Arab-Israeli wars caused oil price hikes increasing the Jamaican oil import bill by more than $\$ J M 100 \mathrm{mn}$. There were food shortages as result of import restrictions and devaluation and controlled prices. The result was that, in the case of Jamaica, retailers hoarded goods to wait for price increases on control priced items. Bank rates increased, gas prices doubled, and car imports cut taxes on cars increased. Nor could the intended social projects, which were supposedly to be funded by tax increases, come on stream. Rather $3 / 4 \%$ of the national budget had to be funded by loans. By 1976, given the rapidly deteriorating economy, lack of economic opportunities along with a rise in the rate of crime, there was a mass migration of businessmen to the

\footnotetext{
${ }^{10}$ Which by January of 1973 resulted in a devaluation of $6.5 \%$ and in February of that year a devaluation of $10 \%$
}

United States. It was estimated that this contributed to a capital flight of over $\$ J M 300 \mathrm{mn}$.

To further compound Jamaica's economic dilemma, during the period 1975- 1976 the world market price for sugar fell. Along with this was a decline in the world demand for bauxite and alumina, Jamaica's primary product. The worst was yet to come, when the island's tourism section, whose main support was over $75 \%$ of tourists from the United States, declined. Part of the problem, apart from political instability and the increase in violent crimes, was the alliance between Jamaica and Cuba; an alliance that was frowned upon the United States. By 1974, it was clear, that Jamaica's only option was to seek external funding. The government looked specifically to the International Monetary Fund (IMF). However, the accompanying Loan had a number of stipulations attached, including a prescription to reduce government expenditures. A number of mechanisms were accordingly recommended.

One mechanism proposed was the reduction in not only the size but also the overall expenditure of the public sector. One of the foreseeable implications of this proposal was that this reduction was to be accompanied by labour cuts. But more was at stake. For instance, if this measure was introduced, it was bound to impact on the delivery of social services such as health, education and welfare benefits as well. Another mechanism suggested, by way of curtailing the spiralling level of inflation within the country, was to increase the rates of interest including land and other kinds of taxes. Perhaps, though, one of the recommendations with the most impact was the privatization of state enterprises. The justification offered for this proposal was that competition of different suppliers into a market would not only reduce monopoly power of a few larger suppliers but competition would lead to lower prices. The prescriptions on how to proceed with the privatization exercise were largely hidden: tax holidays; incentives such as tax breaks; infrastructural reorganizations- all beneficial to the foreign investor.

The Prime Minister, Manley's second term (197680 ) in office, it could be suggested, was characterized by protracted attempts to come to terms with the IMF for economic support. As the economy gradually deteriorated and international reserves dwindled during Manley's first term, the government was forced to approach the IMF for assistance with balance-ofpayments support. Strapped with an ailing economy, 
the Jamaican government agreed to an IMF stabilization program a few months before the 1976 election. The IMF agreed to make a loan to Jamaica if the government undertook large currency devaluation, instituted a wage freeze, and made a greater effort to balance the budget. After the election, however, Manley rejected the IMF recommendations, citing the harsh measures demanded by the Fund in return for balance-of-payments support and arguing that the IMF conditionalities constituted interference in the internal affairs of the country. The implications of acceding to the recommendations of the IMF were frightening. According to McAfee (1991) to accept would have a number of implications? She wrote:

.... the direct involvement of these
agencies has reinforced the region's
impoverishing economic and social
structures, deepened its dependency and
established the conditions for further
economic and social deterioration. Among
the consequences are declining living
standards and decaying social services,
decreasing food self-sufficiency and
degradation of the environment. ${ }^{11}$

The government, in response to the impending crisis in the economy, produced an austerity plan, the Emergency Production Plan of 1977 that emphasized self-reliance and agricultural development. The plan included provisions for establishing a two-tier exchange system and devaluing the Jamaican dollar. Although the plan did not conform to IMF demands, it laid the groundwork for an eventual reconciliation between Manley and the IMF. In other words, the Government of Jamaica was dancing to the IMF's music. In May 1977, IMF negotiators arrived in Jamaica to arrange a twoyear Standby Agreement that was to provide Jamaica with a much needed US\$75 million. The IMF suspended the Standby Agreement in December, however, because Jamaica had failed to meet one of the targets monitored by the IMF on a quarterly basis. Since 1977, seven of the 12 agreements with the IMF were cancelled because Jamaica failed some performance tests. Of the five that were completed, two required special waivers of performance tests by the IMF. The critics of the IMF suggested that the conditions of the loans were too harsh for Jamaica to meet. The defenders of the IMF, on the other hand, felt

\footnotetext{
${ }^{11}$ Kathy McAfee. 1991. Storm Signals. Structural Adjustment and Development Alternatives in the Caribbean. Caledonial Road, London: ZED Books: 16.
}

that governments' mismanagement of the agreements was responsible for the lack of success. In January 1978, the IMF was once again invited to Jamaica to negotiate a three-year Extended Fund Facility (EFF) in the amount of US $\$ 240$ million.

In order to qualify for the EFF, Jamaica devalued its two-tiered currency by $13.6 \%$ (basic rate) and by $5.2 \%$ (special rate). Under the terms of a rigid May 1978 agreement, the government reunified and devalued its currency, agreed to place the currency on a crawlingpeg system of regular devaluations during the next year, imposed new taxes on consumer goods, reduced government expenditures, increased charges for government services, lifted price controls, guaranteed profits for private firms, set a ceiling on wage increases, and limited the activities of several stateowned corporations. The IMF program resulted in exacerbated political and social tensions. Although Jamaica generally followed the terms of the agreement, inflation soared, real wages fell, foreign reserves collapsed, and the trade deficit rose, all of which were expected as part of the short-term adjustment to stabilization policies. The decline in living standards caused by this new agreement led to unrest, violence, and opposition protests. Indeed, this situation led a number of critics to question whether the IMF really understood the challenges facing Jamaica since clearly their prescriptions did not result in any improvements.

Because Jamaica had complied with its policies, however, the IMF increased its lending to Jamaica in June 1979. The new limits for the Extended Fund Facility were set at US $\$ 428$ million to cover the costs of severe floods (which the country had experienced) and the increased price of oil, which skyrocketed again during 1979. Despite the new funding, IMF-Jamaican relations declined in late 1979 as the economy continued to perform poorly even though the country had religiously conformed to the Fund's basic guidelines. Jamaica continued to negotiate with the IMF until March 1980, when Manley broke off negotiations and outlined a new, non-IMF path to economic recovery. It was a plan that was not to be carried out. In the subsequent election of October 1980 , the PNP carried only $41 \%$ of the vote, an apparent repudiation of Manley's policies of initially seeking IMF support and later imposing severe austerity measures on the population.

The election of new Prime Minister, Seaga (October, 1980) marked the beginning of the second major shift in economic policy since independence. The 
Jamaican Labour Party (JLP) was quick to put virtually all of the blame for the steep economic decline of the previous decade on the previous government. Negative growth in the economy, high unemployment, low capacity utilization, flight of skilled labour, high levels of inflation, binding foreign exchange shortage, deep public sector deficit and soaring external indebtedness were all consequences of some of the decisions, or so it was alleged, introduced by the previous government. But... it was suggested, it was not only the poor domestic policies that contributed to the election of a 'new' political regime. Rather, again, hidden forces were at play. McAfee (1991: 126) notes for instance, that the Reagan administration pulled out all the 'stops' to assist the new Prime Minister, Seaga and to keep 'its new Caribbean free enterprise showboat afloat.' No doubt, the socialist leaning of Manley had been a thorn in the side of the US- particularly with the alliance of Jamaica with its arch enemy Cuba. Some suggest, then, that the United States were clearly responsible for the outcome of the election of 1980. MacAfee's observation that economic aid from the United States had escalated from US\$38mn in 1978-1979 to US $\$ 208 m n$ during the period 1981- 1982 making it the third largest per capita recipient of US aid in the world seems to substantiate the suggestion of United States support. Indeed, by 1985 , AID was spending US $\$ 48$ $\mathrm{mn}$ for Jamaica projects, the largest within the Caribbean.

The newly elected government embarked on a number of intensive macro-economic reforms that lasted throughout the 1980s. Some critics suggest, though, that many of these were not policies that were conceived by the domestic policy makers but rather were proposed by the IMF and the World Bank. Indeed, this is plausible particularly when a new IMF deal of over US\$698million was promised over the period of three years. Indeed, if McAfee's account is to be taken seriously, World Bank Aid to Jamaica during the period 1981-1982, constituted more than $67 \%$ of the Bank's total lending in the Caribbean. ${ }^{12}$ Moreover, it was claimed that the Bank was more lenient with the Seaga government than his predecessor and despite the failure of Jamaica to meet the economic targets of the IMF, the Fund agreed to a series of additional loans during the period 1983- 1987 (See Table 1).

One of the primary pursuits of the new government was to improve the performance of the State Owned
Enterprises. For example, the twenty one largest state owned enterprises had a combined operating surplus of $\mathrm{J} \$ 4.5 \mathrm{mn}$ on sales of more than $\mathrm{J} \$ 1.5 \mathrm{bn}$ including net transfers from government of $\mathrm{J} \$ 147.2 \mathrm{mn} .{ }^{13}$ According to Adams and others(1992: 114), the impetus for the reform of these enterprises which were involved with sectors including water, power, telecommunications trade and ports, was that they had a consolidated budget larger than that of the government itself. In terms of their financial programming exercises, then, it was critical to bring these enterprises 'on line' in order to give credit ceilings and deficit targets some macroeconomic meaning. The reforms proposed included the introduction of investment plans, rating reforms and the reorganization of management aimed at commercialization of the enterprises. During the period 1981-1982 there was some improvement in the consolidated financial performance of these enterprises as their current operating balance moved from $-1 \%$ to $6.9 \%$ of the GDP over the period. Additionally, net transfers from the central government moved from $4.5 \%-1.3 \%$ of the GDP or a cumulative improvement of $21.8 \%$ of the GDP. ${ }^{14}$ However, even this small improvement could not be sustained.

Accordingly in 1981, the government embarked on a number of additional privatization exercises. During this period, the Government of Jamaica established a Divestment Committee (DC) with prescribed guidelines and procedures. The Guidelines were based on two fundamental principles. The first was a policy of divestment of equity and control in commercial enterprises at prices based on commercial criteria. The second targeted enterprises which were not commercially viable. But these policies, initially met with little success. During the period 1981- 1985, two small firms were sold, most agricultural marketing boards had been restructured, some hotels had been leased, and some municipal services had been contracted out. Indeed, while some thirty state owned enterprises had been identified for divesture, none had yet gone ahead.

Privatization was not confined to the state enterprises sector but also extended to the agricultural sector as well. Several large foreign companies were invited to the island to manage previously governmentrun activities, especially in the sugar industry. To assist in the process a special, high-profile government

\footnotetext{
${ }^{13}$ Adams, Mistry and Cavendish: 114

${ }^{14}$ Adams, Mistry and Cavendish: 114
} 
Table 1: Selected Loans and Grants to Jamaica $1972-1992^{a}$

\begin{tabular}{|c|c|c|c|c|}
\hline Date & Institution & Title & Type/Identifier & Amount \\
\hline 1977 & IBRD & Public Sector Investment & Program Loan & $\$ 30$ mill \\
\hline 1979 & IBRD & Manufactured Exports & Program Loan & $\$ 31.5$ mill \\
\hline April 1981 & IMF & Extended Fund Facility & & \\
\hline $1982-84$ & IBRD & $\begin{array}{l}\text { Structural Adjustment Loan I, } \\
\text { II, and III }\end{array}$ & 2315-JM, 2478-JM & $\$ 191.4$ mill \\
\hline July 1986 & IMF & Standby Agreement Canceled & & \\
\hline Jan 1987 & IMF & $\begin{array}{l}\text { Standby Agreement } \\
\text { Reinstated }\end{array}$ & & \\
\hline 1987 & IBRD & $\begin{array}{l}\text { Public Enterprise Sector } \\
\text { Adjustment Loan (TFSAL) }\end{array}$ & 2448-JM & $\$ 40$ mill \\
\hline March 1990 & IMF & Standby Agreement & & \\
\hline \multirow[t]{2}{*}{ March 1990} & IBRD & $\begin{array}{c}\text { Ag Sector Adjust. Loan in } \\
\text { Jamaica (ASAL) } \\
\text { 1st tranche, 3/30/90, } \$ 12.5 \mathrm{~m} \\
\text { 2nd tranche, 3/26/91, } \$ 12.5 \mathrm{~m} \\
\text { closed 3/30/91 }\end{array}$ & Loan 3174-JM & $\$ 25$ mill \\
\hline & $\begin{array}{c}\text { OECF (Japan) KFW } \\
\text { (Germany IDB Netherlands) }\end{array}$ & & Co-financing Loans & $\begin{array}{c}\$ 25 \text { mill } \\
\text { DM } 25 \text { mill } \\
\$ 50 \text { mill } \\
\text { NLG } 20 \text { mill }\end{array}$ \\
\hline 1992 & IBRD & $\begin{array}{c}\text { Jamaica Second Trade and } \\
\text { Financial Sector Adjustment } \\
\text { Loan (TFSAL II) }\end{array}$ & Loan 3303-JM & $\$ 30$ mill \\
\hline 1992 & IBRD & $\begin{array}{l}\text { Jamaica Private Sector } \\
\text { Adjustment Loan (PSDAL) }\end{array}$ & & $\$ 60$ mill \\
\hline
\end{tabular}

${ }^{a}$ Economic Integration in the Western Hemisphere, Edited by Constanza Valdes and Terry Rose. Proceedings of a Symposium sponsored by the International Agricultural Trade Research Consortium and the Inter-American Institute for Cooperation on Agriculture, June 7-9, 1995 , San Jose Costa Rica:28.

agency, Agro-21, established as part of the prime minister's office, was created to develop new agricultural products and to modernize farming methods. But this had mixed success; some subsectors such as floral exports and inland fisheries flourished, whereas Agro-21's largest endeavour, the Spring Plains Project was not successful. In other words, the successesof both of these initiatives were limited. Thus, by 1986, it was evident that new measures had to been applied. The aims of the government were prioritized as follows:

- $\quad$ Placing more productive capital under private control;

- $\quad$ The development of a local capital market;

- The stimulation of the involvement of a large number of citizens in the free market system;

- The encouragement of more private investment

- $\quad$ The reduction of fiscal deficits;

- $\quad$ The raising of foreign exchange.
Other initiatives by the Government of Jamaica included the refocusing of exports on 'third country markets', particularly the United States in order to increase trade. The strategy coincided with the duty free importation of goods destined to the United States market covered under the Caribbean Basin Initiative. In the early 1980s the government announced seven priority subsectors where investment and production would be emphasized and foreign exchange would be focused, namely:

*Garments and sewn products;

*Footwear and leather products;

${ }^{*}$ Construction materials;

*Food and agro-industry;

*Automotive products;

${ }^{*}$ Furniture, electronics, and electrical products.

Additionally, emphasis was placed on light or valueadded manufacturing that utilized Jamaica's 
comparative advantage of cheap labour through production-sharing with American or Asian companies. Following on this 'new' industrial policy, the Government of Jamaica established factory spaces in Export Free Zones in prime districts such as the capital city Kingston, Montego Bay and Spanish Town. Most of the export companies were involved in textile manufacturing. Many were American owned. Other measures introduced by the government in order to prevent further haemorrhaging of the economy included, public sector layoffs, the divestment of enterprises, ad hoc sale taxes and comprehensive taxation reform. Other governmental initiatives included the elimination of food subsidies and other price controls, increased public school fees, a reestablishment of university tuition along with a gradual reduction in quantitative restrictions on imports. Clearly, the Government of Jamaica was following rigidly the prescriptions proposed by the International Lending Agencies much to the detriment of its local industries and its citizenry.

The liberal policies applied by the Seaga Government, though, did little to prevent further haemorrhaging of the economy. Between the late 1980 and the end of 1982, Jamaica's trade deficit tripled. New IMF loans accompanied by more austere measures, were introduced to stop further decline but without success. The Jamaican dollar was devalued by $43 \%$ and by 1983 and economic growth had ground to a halt. The rate of inflation accelerated to $30.1 \%$ during the period 1984- 1985 and unemployment climbed to a high of $30 \%$ overall. By 1988, the country's external debt had reached US\$1.875 for ever Jamaican, one of the highest per capita levels in the world. ${ }^{15}$ It seemed a case of dammed if they applied the IMF prescriptions and dammed if they did not.

By 1991, inevitably, Jamaica again entered into negotiations with the IMF. As part of the Structural Adjustment Package with the IMF, the country undertook a rapid process of financial liberalization. The government embarked on a process to eliminate and loosen long standing credit restrictions and interest rate ceilings, a prescription leading to in a rapid expansion of the financial sector. It was clear though that that whiles the policy was introduced, something was obviously missing. Namely, the accompanying regulation. The end result was that because of what some would later describe as the 'reckless' behaviour by financial institutions the country was faced by

\footnotetext{
${ }^{15}$ Much of the data is taken from Mc Afee, 1991: 127
}

widespread bankruptcies during the period 1994. The remedy introduced by the Government was the establishment of the Financial Sector Adjustment Company (FINSAC). This company managed the breakup, nationalization and merging of troubled financial institutions. But it was an intervention that came too late. The Company assumed the debts of the financial companies so that during the period 20002001, an accumulated amounted to over $34 \%$ of the Gross Domestic Product of the country. Clearly, it was a debt that the already cash- strapped government could not afford.

Jamaica's options were limited. Having exhausted all its credit, the only financial organization to which it could turn was the IMF. Its relationship with the Fund had been long-standing. Indeed, the country had near continuous agreements from 1973-1996, a period of more than two decades. It was not surprising then, that in the summer of 2009, in the midst of a severe economic slowdown, the then Finance Minister announced Jamaica's intention to secure another new IMF agreement. This 27 month Stand-by-Arrangement worth $\$ 1.27$ billion was approved by the Executive Board on February 4, 2010 allowing Jamaica to immediately receive the first tranche of financing in the amount of US $\$ 640$ million. Entering into this agreement also meant that funding from other multilateral organizations, including $\$ 450$ million from the World Bank and $\$ 600$ million from the Inter-American Development Bank (IADB) could be sourced. This time, the conditions constituted a three part strategy consisting of the following measures:

(a) Medium term fiscal considerations;

(b) Lowering of the interest costs and addressing debt over hang programs;

(c) Reform of the financial sector.

Again, these conditions met with a number of criticisms since according to many, the prescriptions were merely a rehash of the early prescriptions offered by the IMF. Moreover, in hindsight, they were prescriptions that had failed to bring around any significant improvements. By 2011, however, Jamaica's agreement with the IMF stalled, reportedly over the Jamaican government's paying of back wages owed to public sector employees ${ }^{16}$. Clearly, it was a decision

\footnotetext{
${ }^{16}$ Jake Johnston and Juan A. Montecino .Update on the Jamaican Economy May 2012. Center for Economic Policy and Research. 1611 Connecticut Avenue, NW, Suite 400 Washington, D.C. 20009
} 
over which the Jamaican Government had little control, since this decision was premised by the Industrial Disputes Tribunal and Supreme Court rule in favour of the public sector employees. Even though it was a decision over which the government may have little control, the end result was that the IMF stopped reviewing the Jamaican economy and ceased the disbursement of funding. But the worst was yet to follow. Other multilaterals such as The World Bank, Inter-American Development Bank and European Union, following on the experience of the IMF all curtailed spending in 2011 following the IMF's decision. Even though the agreement with the IMF had stalled, however, it was evident that the Government of Jamaica was still adhering to many of the conditions this no doubt led to some improvements in several of the socio-economic and environmental indicators. Indeed, despite many setbacks, the country recorded real Gross Domestic Product growth of $1.5 \% .{ }^{17}$ This had followed three consecutive years of economic contractions which were mainly attributed to the impact of the global economic crisis.

During this period, too, the Goods Producing and Services Industry grew by $5.0 \%$ and $0.1 \%$ respectively. ${ }^{18}$ No doubt many felt that the economy could have done significantly better if it were not for several international developments which adversely impacted on Jamaica's performance. These included among others:

(a) The Standard and Poor's downgrade of the United States economy from AAA to AA+ which resulted in the loss of wealth and a slowdown in economic activities in the United States;

(b) An Intensification of the debt crisis in the Eurozone which resulted in a slowing in the pace of growth in industrial activities. This was accompanied by a contraction in the demand along with a weakening in the price of inputs such as alumina.

Locally, the impact of these international developments resulted in slower than expected growth in key tradable sectors in the country such as Agriculture, Forestry and Fishing, Mining and Quarrying, Manufacturing and Tourism. The real GDP growth in the first half of 2011 was $1.9 \%$ while in the

\footnotetext{
${ }^{17}$ Planning Institute of Jamaica. Selected indicators.

${ }^{18}$ The industries which contributed most to this growth were Mining and Quarrying, Agriculture and Forestry and Fishing.
}

second half of the year it slowed to $1.1 . \%$. Other challenges associated with these developments included:

- $\quad$ Slower growth in employment along with the concomitant increase in the level of unemployment;

- A widening of the current account deficit of the country;

- $\quad$ Further deterioration in the fiscal balances of the country as growth in tax revenue was dampened.

In spite of these challenges ${ }^{19}$, though, the country experienced improved macro-economic stability. The rate of inflation in the country was $6.0 \%$, which represented the lowest rate since 2006 . There was also a relative stability in the exchange rate with $0.9 \%$ depreciation. Interest rates trended downwards as indicated by $2.4 \%$ points decline in the monthly weighted average loan rates.

On May 1, 2013, the Government of Jamaica once again entered into a formal arrangement with the IMF with the approval of a four-year agreement under the Extended Fund Facility. The loan agreement was valued at special drawing rights (SDR) of 615.38 million or US\$932 million. Not unexpectedly, there were four conditions attached. These included entering into a three- year wage restraint agreement with the Trade Unions; the implementation of a National Debt Exchange (NDX) programme which involved the exchange of existing domestic bonds with new bonds of lower coupon rates and longer maturity payments; the suspension in the granting of discretionary waivers and placing a cap on total waivers until the new Omnibus Incentive Regime was established; and finally the implementation of a Public Debt Law geared at strengthening the debt management process. In the two quarterly reviews by the IMF (April- June; July September) it was reported that Jamaica complied successfully. As if as a reward, there were some gains. For 2013, Real Gross Domestic Product (GDP) grew by 0.2 per cent relative to 2012 . This performance reflected increases of $0.4 \%$ and $0.1 \%$ in the Goods Producing and Services Industries. Within the Goods

\footnotetext{
${ }^{19}$ Much of this data is taken from an article by Jake Johnston and Juan A. Montecino .Update on the Jamaican Economy. May 2012. Center for Economic Policy and Research. 1611 Connecticut Avenue, NW, Suite 400 Washington, D.C. 20009
} 
Producing Industry, increases were recorded by the Mining \& Quarrying and the Construction industries. The performance of the Services Industry was driven by growth recorded for Hotels \& Restaurants and Finance \& Insurance Services.

Nonetheless in 2014, Jamaica as a country is still faced with numerous challenges. For one, growth is too low, and unemployment and public debt are much too high. On the brighter side, however, IMF projections show debt-to-GDP declining from 146 per cent of GDP in March 2013 to 138 per cent of GDP by the end of this fiscal year 2014. While clearly this is a significant gain in one year -- the debt remains much too high for comfort. Many suggest that gradually reducing debt-toGDP to a more manageable level will be critical to increase investor confidence, reduce crisis risks, and provide policy space in case of natural disasters. The question is- can Jamaica really do this?

\section{SUMMARY}

Jamaica is clearly one country who has had a long standing relationship with the IMF and World Bank. However, to date the prescriptions recommended by these lending agencies have had relatively little success. Some suggest that perhaps the problem may have been due to the ill-conceived domestic policies conceived by newly elected governments. Others ascribe much of the blame to global forces over which small island states have little control. Yet, others suggest that the IMF and World Bank initiate policies that are not in keeping with the needs of small island states or their citizenry. Whether it is global forces or the prescriptions offered by the lending agencies, what is evident is that Jamaica has a long, long way to go before the country could manoeuvre out of the debt crisis that currently obtains.

\section{REFERENCES}

Christopher Adam, William Cavendish and Percy S Mistry. Adjusting privatization. Case Studies from developing Countries. James Currey Ltd, Islington, London: 1992.

G. L. Beckford. (2000) "The Future of Plantation Society in Comparative Perspective," in G.L. Beckford and K. Polanyi Levitt, The George Beckford Papers: Selected and Introduced by Kari Levitt, Mona, Jamaica: Canoe Press, University of the West Indies, 336-46.

Lloyd Best, and K. Polanyi Levitt. (2007) Plantation Economy: A Historical and Institutional Approach To Caribbean Economic Transformation, Mona, Jamaica: University of the West Indies Press.

C, Furtado.(1963) the Economic Growth of Brazil, Berkeley: University of California Press.

Norman Girvan. (2002) "Notes for a Retrospective on the Theory of Plantation Economy of Lloyd Best and Kari Polanyi Levitt," in M-C Dernò and K.Nurse (eds.) Caribbean Economies and Global Restructuring, Kingston, Jamaica: lan Randle Publishers for the Association of Caribbean Economists.

Jake Johnston. (2013) The Multilateral debt Trap in Jamaica. Centre for Economic Policy Research, June: 1

Jake Johnston and Juan A. Montecino .Update on the Jamaican Economy. May 2012. Center for Economic Policy and Research. 1611 Connecticut Avenue, NW, Suite 400 Washington, D.C. 20009

Kathy McAfee. 1991. Storm Signals. Structural Adjustment and Development Alternatives in the Caribbean. Caledonial Road, London: ZED Books

Contanza Valdez and Terry Roe Economic Integration in the Western Hemisphere (Edited), April, 1997, Proceedings of a Symposium Sponsored by the International Agricultural Trade Research Consortium and the Inter-American Institute for Cooperation on Agriculture June 7-9, 1995 San Jose, Costa Rica.

\footnotetext{
${ }^{20}$ Economic Select Indicators 2013.
}

\section{DOI: http://dx.doi.org/10.6000/1929-7092.2014.03.15}

(c) 2014 Ann Marie Bissessar; Licensee Lifescience Global.

This is an open access article licensed under the terms of the Creative Commons Attribution Non-Commercial License (http://creativecommons.org/licenses/by-nc/3.0/) which permits unrestricted, non-commercial use, distribution and reproduction in any medium, provided the work is properly cited. 